Mots. Les langages du politique

Discours présidentiels et de présidentielles

\title{
Hommage à Bertrand Pirat
}

\section{Paul Bacot}

\section{OpenEdition}

\section{Journals}

Édition électronique

URL : https://journals.openedition.org/mots/22416

DOI : $10.4000 /$ mots. 22416

ISSN : 1960-6001

\section{Éditeur}

ENS Éditions

\section{Édition imprimée}

Date de publication : 15 octobre 2016

Pagination : 19-20

ISBN : 978-2-84788-850-8

ISSN : 0243-6450

\section{Référence électronique}

Paul Bacot, « Hommage à Bertrand Pirat », Mots. Les langages du politique [En ligne], 112 | 2016, mis en ligne le 15 octobre 2016, consulté le 28 juin 2022. URL : http://journals.openedition.org/mots/22416 DOI : https://doi.org/10.4000/mots.22416

\section{(c) ENS Éditions}




\section{Hommage à Bertrand Pirat}

Il y a quatre ans, Bertrand Pirat nous quittait brutalement. Il était l'un des responsables de la Société d'étude des langages du politique. Auteur d'une thèse originale sur «Présider. Les modes ordinaires de formalisation de quelques figures présidentielles», il avait confié à notre revue deux articles : «Oui ou non. Le piège rhétorique du référendum » (2007, n 83, p. 139-153) et «En haut et au centre. La prééminence présidentielle» (2002, nº68, p.59-72). En hommage à son auteur, nous renvoyons ici à cette seconde contribution*, qui s'appuyait sur plusieurs livres consacrés au président Mitterrand et traitait donc du discours sur un président. Elle aurait pu constituer un bon prologue à ce numéro entièrement consacré aux discours présidentiels et de présidentielles.

* http://mots.revues.org/6803 
